\title{
Hyaluronan Mediated Motility Receptor
}

National Cancer Institute

\section{Source}

National Cancer Institute. Hyaluronan Mediated Motility Receptor. NCI Thesaurus. Code C21103.

Hyaluronan mediated motility receptor $(724 \mathrm{aa}, \sim 84 \mathrm{kDa})$ is encoded by the human HMMR gene. This protein is involved in the modulation of cell motility. 